\title{
Influence of Physical Activity in Patients with Prostate Cancer Undergoing Radiotherapy and/or Hormonal Deprivation Therapy: Integrative Literature Review
}

\author{
Caio Augusto de Ávila Silva ${ }^{1}$, Gabriel Dias Monteiro ${ }^{1}$, Gustavo Pereira Freitas ${ }^{1}$, João Vitor Coppola \\ Oliveira ${ }^{1}$ and Douglas Reis Abdalla ${ }^{1,2^{*}}$ \\ ${ }^{1}$ Medicine Student, University of Uberaba, Brazil \\ ${ }^{2}$ Health Courses, Faculty of Human Talents, Brazil

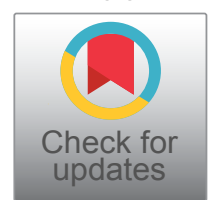

*Corresponding author: Douglas Reis Abdalla, Medicine Student, University of Uberaba, Av. Tonico dos Santos, 333 Jardim Induberaba, Uberaba, Minas Gerais, Brazil

\begin{abstract}
Introduction: In Brazil and in the world, the incidence and prevalence of prostate cancer have been increasing. The prostate is a male gland responsible for the production of part of the semen. More than any other type, it is considered a cancer of the third age, since about $75 \%$ of the cases in the world occur from the age of 65 . In this study it was correlated the practice of physical exercises with the progression and evolution of the disease beyond the impacts in the treatment
\end{abstract}

Aim: This work aimed to verify in the literature the impacts of regular physical activity on patients with prostate cancer under treatment and after treatment.

Methods: Systematic search of scientific articles published between 2010 and 2020 in the PubMed database, using the descriptors: Prostate cancer, Physical activity, Exercise, Quality of life and Lifespan. After complete analysis of the publications, seven articles met all inclusion criteria.

Results: Overall improvement was observed in those patients who started the physical activity program, as well as improvement in quality of life, physical function, weight, body fat, well-being-psychological and reduction of cardiovascular risk, weight, fatigue, blood markers and inflammatory cytokines.

Conclusion: Physical activity is an additional resource in the treatment of patients with prostate cancer.

\section{Keywords}

Prostate Cancer, Physical activity, Exercise, Quality of Life, Lifespan

\section{Introduction}

Prostate Cancer (PC) is the fifth most common cancer in the worldwide and the second most common neoplasia among men [1]. According to the global cancer observatory site, $\mathrm{PC}$ is the most prevalent in Brazil and among men its incidence is 74 cases per 100,000 habitants, followed by colorectal cancer with an incidence of 21.1. See official data from the World Health Organization and the American Cancer Society in 2018 there were 1,280,000 cases diagnosed and 359,000 deaths worldwide by PC. Analyzing these data it is concluded that their prevalence has been growing globally, requiring a solid policy of prevention.

Most PCs are asymptomatic at the beginning and slow growing, however, over time cause compressive symptoms in patients. Therefore, it can lead to frequent urination, nocturia and difficulty to initiate and maintain the flow of urination.

According to Hall and colleagues [2], the main metastatic focus for advanced prostate carcinoma is bones. Being, in its majority, in the axial skeleton (spine, ribs and pelvis), such involvement makes difficult an intervention with physical exercises in these patients, given the intense bone pain present, besides possible comorbidities that may develop as limitation of physical function and hypercalcemia.

Citation: Silva CAA, Monteiro GD, Freitas GP, Oliveira JVC, Abdalla DR (2021) Influence of Physical Activity in Patients with Prostate Cancer Undergoing Radiotherapy and/or Hormonal Deprivation Therapy: Integrative Literature Review. Int J Sports Exerc Med 7:192. doi.org/10.23937/2469-5718/1510192 Accepted: June 03, 2021; Published: June 05, 2021

Copyright: (c) 2021 Silva CAA, et al. This is an open-access article distributed under the terms of the Creative Commons Attribution License, which permits unrestricted use, distribution, and reproduction in any medium, provided the original author and source are credited. 
For Owen and collaborators [3], the comorbidities associated with Hormonal Deprivation Therapy (HDT) are derived from hypogonadism caused. Loss of lean mass, fat gain and drastic reduction of bone mass are the main problems that appear in individuals who perform HDT. In addition, there are those that are triggered by these factors such as: Increased cardiovascular risk, diabetes and high risk of fractures.

In accordance with Teo; Rathkopf; Kantoff [4], the therapeutic scenario of PC in recent years has been transformed with the use of advanced functional imaging, state-of-the-art sequencing and better use of existing therapies in the early stage disease. Depending on factors such as disease staging, comorbidities, patient age and lifespan, the main treatment options for men with prostate cancer may include expectant behavior, surgery, radiotherapy, cryosurgery, hormone therapy, immunotherapy, chemotherapy and treatment of the spread of the disease to the bones.

Although survival rates have risen and advances in diagnosis and treatment have been made, cancer is still received as a death sentence and brings with it psychological consequences such as fear, sadness and depression [5]. In addition, it is known that there are complications from prostate cancer treatment that can have an impact on urinary and sexual function, such as urinary incontinence and erectile dysfunction that affect marital life and generate losses in the quality of life of patients, including the psychological aspect [6]. According to Talcott; Clark [7], the quality of life related to health has been of great importance and has entered the medical literature in recent years, being a crucial point in clinical care.

There is evidence that planned exercise is a possible adjunctive strategy linked to significant improvements in outcomes related to debilitating symptoms of cancer, including prostate cancer, where there is improvement in exercise tolerance, physical functioning during conventional adjuvant therapy, thus resulting in improved quality of life [8].

Such facts are because exercise results in reductions in obesity and oxidative stress and a modulation of immune responses in prostate cancer. Exercise causes reductions in circulating levels of testosterone and insulin-like growth factors, thereby reducing the development and spread of neoplastic cells. In addition to exercise, testosterone levels are controlled by diet, and this may contribute to the variations in responses to exercise among various populations $[9,10]$.

Thus, this work aimed to verify in the literature the impacts of regular physical activity on patients with prostate cancer under treatment and after treatment.

\section{Methods}

In this work an integrative review was performed.
This, in summary, is a research that allows the knowledge about a certain subject or theme, whose purpose, based on pre-existing studies, is to produce a broad view of concepts, theories or relevant health problems and enable the proposition of intervention $[11,12]$.

The choice of articles was made following a methodological sequence, consisting of 6 stages, which are: 1) Preparation of the guiding question or research hypothesis; 2) Definition of inclusion and exclusion criteria of the articles to be selected for the composition of the sample; 3 ) Exploratory reading of the titles and abstracts of the articles; 4) Analytical reading of the articles in order to select, examine and organize information; 5) Interpretation of results; 6) Compendium followed by presentation of the results analyzed, which are related to the guiding question [13].

In the present study, we chose to search the following concepts: Prostate, tumor, prostate cancer, physical activity. Then, based on these keywords, the guiding question of the work was produced: What are the impacts of regular physical activity on quality of life in patients with prostate cancer under treatment or after treatment?

After developing the guiding question, a scan of the PubMed database was done from September to October 2020. For the selection of publications related to the theme, we used the filters available in the platform for texts published between January 2010 to December 2020. Thus, the following inclusion criteria were adopted: Scientific articles, published in the English language, from 2010 to 2020, available online and free of charge in full. The publications excluded were: Articles without abstracts in the database or incomplete, editorials, letters to the editor, reflective studies, systematic or integrative literature reviews.

After the development of the guiding question, location and selection of articles, 140 potentially eligible publications were identified to be part of this work. With the introduction of inclusion and exclusion criteria, the sample consisted of 42 articles. In order to ascertain whether the publications would meet the eligibility criteria and answer the question that guides this review, abstracts of 26 records were examined, of which 19 were excluded and only 7 were analyzed in full to confirm eligibility for quantitative synthesis and data analysis. The flowchart (Figure 1) below summarizes the selection of publications.

\section{Results and Discussion}

In the time frame set for this study (2010-2020) 7 publications were found and analyzed (Table 1). In 2015 and 2017, 2 articles (57.1\%) were published each year respectively, already in 2016, 2018 and 2019 there is only 1 publication in each year (42.9\%).

The publications resulted from different journals be- 


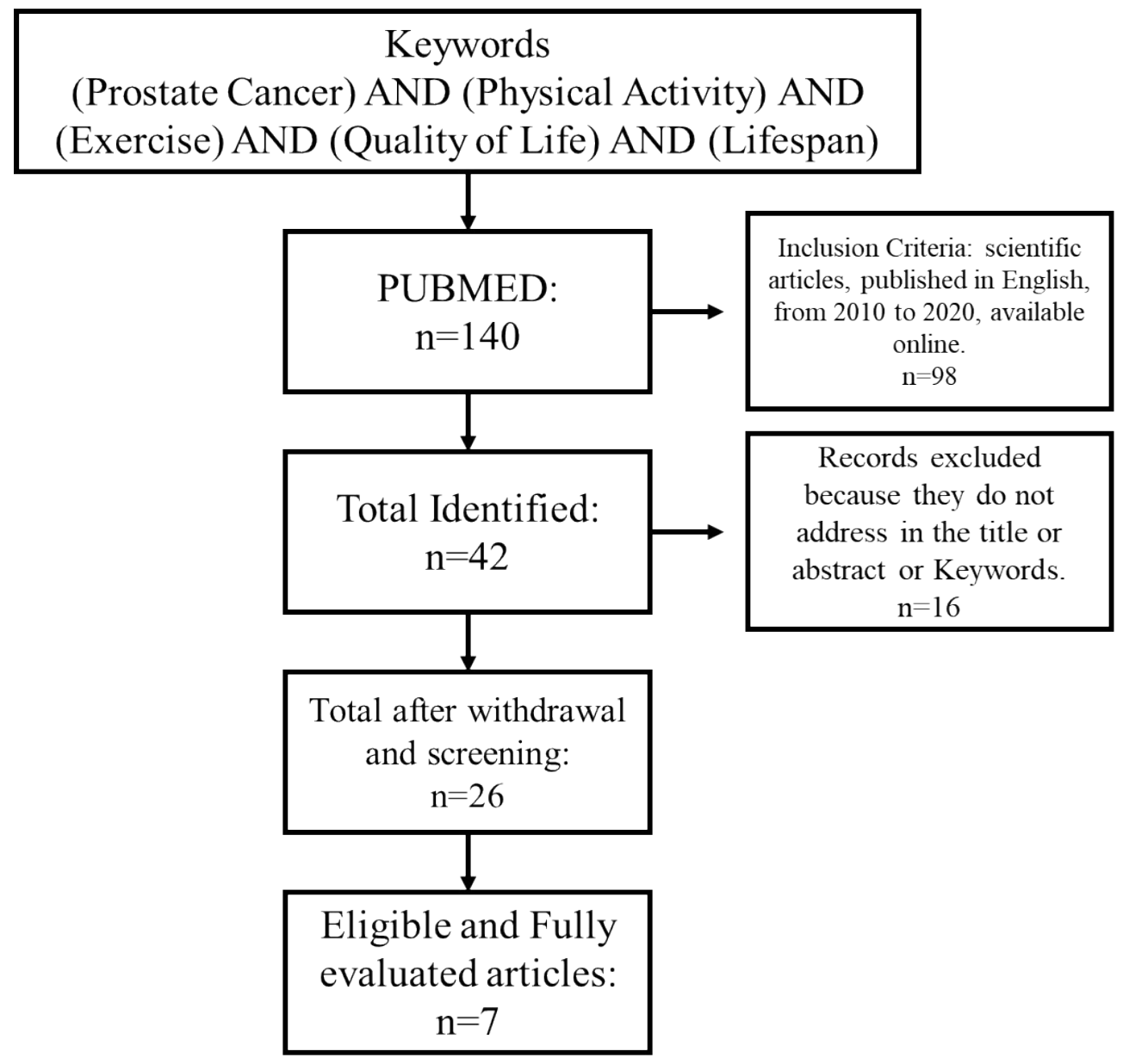

Figure 1: Publication selection flowchart.

ing: Cancer, BMC Cancer, European Urology, BMJ Open, Polish Archives of Internal Medicine and European Journal of Physical and Rehabilitation Medicine. Analyzing the study sites, 2 articles were conducted in the Australia (28.6\%), 2 articles in the Poland (28.6\%), 1 article in United States of America (14.27\%), Netherlands (14.27\%) and United Kingdon (14.27\%).

The Table 1 summarizes the articles that investigated the influence of physical activity on the quality life in Prostatic Cancer patients. The articles are listed according to the topic of relationship between prostate cancer, physical activity and quality of life, as well as in the chronological order of publication.

\section{Physical Activity and Hormonal Deprivation Therapy}

Dawson and Collaborators [14], promoted a study to investigate the effects of 12 weeks of resistance training and protein supplementation in men with prostate cancer and undergoing treatment with HDT. 40 volunteers were divided in 4 groups, which were: 1) Resistance training with protein supplementation; 2) Only resistance training; 3) Only protein supplementation and 4) Control. After the interventions, it was observed that the groups submitted to physical activity significantly improved the lean mass, sarcopenia, body fat, strength and quality of life, when compared to the groups not submitted to physical exercise.

In this context, Taaffe and Collaborators [15], sought to determine the long-term effects of different modes of exercise on fatigue. Between 2009 and 2012, 163 patients with prostate cancer in HDT were randomized to participate in the study. Of these patients, 58 practiced exercises for the musculoskeletal system with impact load and endurance training for 12 months; 54 patients exercised the cardiovascular and muscular systems with aerobic and endurance training for 6 months and a further 6 months of home training and 51 patients did usual care for 6 months, followed by exercise on an exercise bike for 6 months. They concluded that fatigue was reduced in the groups with impact and resistance exercises at 6 months and 12 months, and in the other groups at 12 months. Likewise, vitality increased for all groups in 12 months. Those with the highest levels of fatigue and least vitality improved the most with exercise.

\section{Physical Activity and Radiation Therapy}

In the article written by Hojan, et al. [16], in which they evaluated the effect of supervised physical exercise on inflammatory blood markers, as well as the relationship of these parameters with functional capacity, fatigue and Quality of Life in patients with high-risk prostate cancer 
Table 1: List of articles that investigated the influence of physical activity on the quality life in Prostatic Cancer patients.

\begin{tabular}{|c|c|c|c|c|}
\hline Reference & $\begin{array}{l}\text { Intervention - Physical } \\
\text { Activity }\end{array}$ & Studied Variables & Main Results & Conclusion \\
\hline & & \multicolumn{3}{|c|}{ Physical Activity And Hormonal Deprivation Therapy } \\
\hline $\begin{array}{l}\text { Taffe, et al. } \\
{[15]}\end{array}$ & $\begin{array}{l}\text { Different modalities of physical } \\
\text { exercises (impact exercises, } \\
\text { endurance, aerobic, retarded } \\
\text { exercises). }\end{array}$ & $\begin{array}{l}\text { Vitality } \\
\text { Fatigue }\end{array}$ & $\begin{array}{l}\uparrow \text { Vitality } \\
\downarrow \text { Fatigue }\end{array}$ & $\begin{array}{l}\text { Reduction of fatigue and } \\
\text { increase in vitality during } \\
\text { HDT. }\end{array}$ \\
\hline \multirow[t]{2}{*}{$\begin{array}{l}\text { Dawson, et } \\
\text { al. [14] }\end{array}$} & $\begin{array}{l}\text { Resistance training and protein } \\
\text { supplementation for } 12 \text { weeks. }\end{array}$ & $\begin{array}{l}\text { Sarcopenia } \\
\text { Body fat } \\
\text { Strength } \\
\text { Quality of Life }\end{array}$ & $\begin{array}{l}\downarrow \text { Sarcopenia } \\
\downarrow \text { Body fat } \\
\uparrow \text { Strength } \\
\uparrow \text { Quality of Life }\end{array}$ & $\begin{array}{l}\text { Improved sarcopenia, body } \\
\text { fat percentage, strength and } \\
\text { quality of life, not changing } \\
\text { metabolic syndrome and } \\
\text { physical function. }\end{array}$ \\
\hline & & \multicolumn{3}{|c|}{ Physical Activity AndRadiation Therapy } \\
\hline \multirow[t]{2}{*}{$\begin{array}{l}\text { Hojan, et al. } \\
{[16]}\end{array}$} & $\begin{array}{l}\text { Supervised physical exercise of } \\
\text { moderate intensity. }\end{array}$ & $\begin{array}{l}\text { Inflammatory } \\
\text { markers } \\
\text { Functional capacity } \\
\text { Fatigue } \\
\text { Quality of Life }\end{array}$ & $\begin{array}{l}\uparrow \text { Functional capacity } \\
\uparrow \text { Quality of Life } \\
\downarrow \text { Level of inflammatory } \\
\text { cytokines } \\
\downarrow \text { Fatigue }\end{array}$ & $\begin{array}{l}\text { Improved quality of life and } \\
\text { functional capacity, as well as } \\
\text { reduced fatigue and levels of } \\
\text { inflammatory markers. }\end{array}$ \\
\hline & & \multicolumn{3}{|c|}{$\begin{array}{c}\text { Physical Activity Associated With Radiation Therapy And Hormonal } \\
\text { Deprivation Therapy }\end{array}$} \\
\hline \multirow[t]{2}{*}{$\begin{array}{l}\text { Hojan, et al. } \\
\text { [22] }\end{array}$} & $\begin{array}{l}\text { Supervised physical exercise } \\
\text { for } 12 \text { months, evaluation of } \\
\text { inflammatory, cardiometabolic } \\
\text { and functional parameters. }\end{array}$ & $\begin{array}{l}\text { Quality of Life } \\
\text { Fatigue } \\
\text { Functional capacity } \\
\text { Level of } \\
\text { inflammatory } \\
\text { cytokines } \\
\text { Waist-to-Hip Ratio }\end{array}$ & $\begin{array}{l}\uparrow \text { Quality of Life } \\
\uparrow \text { Functional capacity } \\
\downarrow \text { BMI } \\
\downarrow \text { Waist-to-Hip Ratio } \\
\downarrow \text { Level of inflammatory } \\
\text { cytokines } \\
\downarrow \text { Fatigue }\end{array}$ & $\begin{array}{l}\text { Significant improvement } \\
\text { in quality of life, functional } \\
\text { capacity, reduction of BMI } \\
\text { and levels of inflammatory } \\
\text { cytokines. }\end{array}$ \\
\hline & & \multicolumn{3}{|c|}{ Physical Activity After Treatment For Prostate Cancer } \\
\hline $\begin{array}{l}\text { Buffart, et al. } \\
\text { [23] }\end{array}$ & $\begin{array}{l}\text { Effects of physical activity } \\
\text { (aerobic and endurance) for } 12 \\
\text { months on the quality of life of } \\
\text { prostate cancer survivors. }\end{array}$ & $\begin{array}{l}\text { Quality of Life } \\
\text { Physical function } \\
\text { Social function }\end{array}$ & $\begin{array}{l}\uparrow \text { Quality of Life } \\
\uparrow \text { Physical and Social } \\
\text { function }\end{array}$ & $\begin{array}{l}\text { Improvement of quality of life, } \\
\text { physical function and social } \\
\text { function. }\end{array}$ \\
\hline $\begin{array}{l}\text { Livingston, et } \\
\text { al. [24] }\end{array}$ & $\begin{array}{l}\text { 12-week exercise program } \\
\text { indicated by a doctor for men } \\
\text { who have completed active } \\
\text { treatment for prostate cancer. }\end{array}$ & $\begin{array}{l}\text { Psychological well- } \\
\text { being } \\
\text { Quality of Life } \\
\text { Blood pressure } \\
\text { Submaximum } \\
\text { fitness } \\
\text { Body Mass }\end{array}$ & $\begin{array}{l}\uparrow \text { Quality of Life } \\
\downarrow \text { Blood pressure }\end{array}$ & $\begin{array}{l}\text { Improvement of depressive } \\
\text { symptoms, quality of life } \\
\text { (improved cognitive function), } \\
\text { levels of physical conditioning } \\
\text { and physical and mental } \\
\text { health. }\end{array}$ \\
\hline $\begin{array}{l}\text { Lemanska, } \\
\text { et al. } \\
\text { [25] }\end{array}$ & $\begin{array}{l}\text { Intervention with physical } \\
\text { exercises and diet, through } \\
\text { community pharmacies, for } 3 \\
\text { months. }\end{array}$ & $\begin{array}{l}\text { Weight } \\
\text { Strength } \\
\text { Quality of Life } \\
\text { Cardiovascular } \\
\text { Risk }\end{array}$ & $\begin{array}{l}\uparrow \text { Quality of Life } \\
\downarrow \text { Weight } \\
\downarrow \text { Cardiovascular Risk } \\
\uparrow \text { Strength }\end{array}$ & $\begin{array}{l}\text { Improved quality of life, } \\
\text { weight, strength and drop in } \\
\text { cardiovascular risk. }\end{array}$ \\
\hline
\end{tabular}

undergoing Radiation Therapy (RT), 2 groups were created: Study Group (27 men) and Control Group (27 men) for the intervention that would be regular Physical Exercise of moderate intensity. There were no significant differences between the study groups in the initial evaluation. After the intervention with physical activity, there was a significant improvement in functional capacity and a decrease in levels of pro-inflammatory cytokines and fatigue. The level of fatigue was significantly higher in the control group after RT than before. It was concluded that regular exercise of moderate intensity improved functional capacity, decreased the production of inflammatory markers and fatigue and positively influenced the quality of life during the period of RT. 
Regarding the influence of physical activity on the immune system in the presence of tumors, preclinical and clinical studies show that practicing physical activity changes the patterns of immune responses to antitumor cellular profiles, at systemic and intratumoral levels, leading to the control of the inflammatory state and potentiating a response of rejection to the tumor, with synthesis of cytokines of profile 1 of T helper lymphocytes, profile 1 of macrophages and improving the maturation of dendritic cells [17-21].

\section{Physical Activity Associated with Radiation Therapy and Hormonal Deprivation Therapy}

Hojan and his collaborators [22], conducted a study to evaluate the effect of a 12-month exercise program on inflammatory and cardiometabolic parameters, as well as on functional status, in patients with prostate cancer who underwent radiotherapy and androgen deprivation therapy. Thus, 72 volunteers were divided into 2 groups (exercise group and control group). It was observed a significant improvement in quality of life, functional capacity, BMI, waist-to-hip ratio and decreased level of inflammatory cytokines and fatigue in the exercise group compared to the control group.

\section{Physical Activity after Treatment for Prostate Cancer}

According to Buffart, et al. [23], they examined the effects of physical activity for 12 months on the quality of life of prostate cancer survivors. The study was attended by 100 individuals, mean age 71.7 years, which were divided into two groups: 1) EX: Book with detailed instructions for resistance exercises and performing aerobic exercises; 2) AF: Educational book with recommendations for performing 150 minutes of aerobic activity per week. It was demonstrated that the aerobic and resistance exercises generated a beneficial effect for the EX group, increasing the quality of life and maintaining the physical and social function in relation to the PA group. However, even with the beneficial effects being significant, little has changed in the clinic of these patients. It is also worth mentioning that the only effects that remained after the study were those related to physical function.

Similar results were obtained by Livingston, et al. [24], who evaluated the effectiveness of a 12-week exercise program indicated by a doctor for men who have completed active treatment for prostate cancer. In this study, two groups were selected: Intervention Group (54 men) and Control Group (93 men), with an average age of 65.6 years. The effects of the exercise program on psychological well-being, quality of life and objective evaluation of physical activity were evaluated. They also evaluated variables such as blood pressure, submaximal fitness, body mass. As a result they noticed improvement in depressive symptoms, quality of life (improved cognitive function), levels of physical conditioning and physical and mental health.
In a study conducted by Lemanska, et al. in 2019 [25], the acceptability and feasibility of an intervention with physical exercise and diet, through community pharmacies, in the health and physical activity of men with prostate cancer were evaluated. In this study was used 116 men with an average age of 70.4 years whose treatment for prostate cancer had already been terminated at least 3 months before the study. A personalized exercise program was applied for each of the participants, through a DVD with instructions for exercises and dietary advice to be followed. They were accompanied by a pharmacist through 2 phone calls and a consultation 3 months after the first evaluation. The individuals presented weight reduction and strength increase. The study concluded that this training of community pharmacies improved the quality of life and decreased cardiovascular risk.

\section{Conclusion}

From the studies presented in this integrative review, we can conclude that there are a limited number of studies about the evaluation of the influence of physical activity in patients with prostate cancer. Regarding the positive impacts of physical activity on quality of life in patients with prostate cancer, the articles showed that both physical activity during treatment, whether isolated or combined between RT and HDT, and after treatment, improved the quality of life of patients, being responsible for increasing vitality, strength and functional capacity and reducing sarcopenia, fatigue, body fat, inflammatory markers, BMI, blood pressure and cardiovascular risk. Finally, it is suggested that further studies should be conducted to confirm and to enhance the implementation of physical activity in this population.

\section{Authors Contribution}

All authors contributed equally to the development of this work.

\section{References}

1. Bray F, Ferlay J, Soerjomataram I, Siegel RL, Torre LA, et al. (2018) Global cancer statistics 2018: GLOBOCAN estimates of incidence and mortality worldwide for 36 cancers in 185 countries. CA Cancer J Clin 68: 394-424.

2. Hall CL, Dubyk CW, Riesenberger TA, Shein D, Keller ET, et al. (2008) Type I collagen receptor ( $\alpha 2 \beta 1)$ signaling promotes prostate cancer invasion through RhoC GTPase. Neoplasia 10: 797-803.

3. Owen PJ, Daly RM, Livingston PM, Mundell NL, Dalla Via $\mathrm{J}$, et al. (2017) Efficacy of a multi-component exercise programme and nutritional supplementation on musculoskeletal health in men treated with androgen deprivation therapy for prostate cancer (IMPACT): study protocol of a randomised controlled trial. Trials 18: 451.

4. Teo Min Yuen, Dana E Rathkopf, Philip Kantoff (2019) Treatment of advanced prostate cancer. Annual Review of Medicine 70: 479-499.

5. Seemann, Taysi, et al. (2018) Influence of symptoms of depression on the quality of life of men diagnosed with prostate cancer. Revista Brasileira de Geriatria e Gerontologia 21: $70-78$. 
6. De Sousa A, Sonavane S, Mehta J (2012) Psychological aspects of prostate cancer: a clinical review. Prostate Cancer Prostatic Dis 15: 120-127.

7. Talcott JA, Clark JA (2005) Quality of life in prostate cancer. Eur J Cancer 41: 922-931.

8. Deb AA, Okechukwu CE, Emara S, Abbas SA (2019) Physical activity and prostate cancer: a systematic review. Urol Nephrol Open Access J 7: 117-129.

9. Shephard RJ, Shek PN (1998) Associations between physical activity and susceptibility to cancer. Sports Med 26: 293315.

10. Wekesa A, Harrison M, Watson RW (2015) Physical activity and its mechanistic effects on prostate cancer. Prostate Cancer Prostatic Dis 18: 197-207.

11. Galvão CM, Sawada NO, Trevizan MA (2004) Systematic review: a resource that allows the incorporation of evidence into nursing practice. Rev Latino-am Enfermagem 12: 549546.

12. Whittemore R, Knafl K (2005) The integrative review: updated methodology. J Adv Nurs 52: 546-553.

13. De Sousa LD, Lunardi Filho WD, Lunardi VL, Santos SS, Dos Santos CP (2011) The nursing scientific production about the clinic: an integrative review. Rev Esc Enferm USP (SP) 45: 494-500.

14. Dawson JK, Dorff TB, Shroeder ET, Lane CJ, Gross ME, et al. (2018) Impact of resistance training on body composition and metabolic syndrome variables during androgen deprivation therapy for prostate cancer: A pilot randomized controlled trial. BMC Cancer 18: 368.

15. Taaffe DR, Newton RU, Spry N, Joseph D, Chambers SK, et al. (2017) Effects of Different Exercise Modalities on Fatigue in Prostate Cancer Patients Undergoing Androgen Deprivation Therapy: A Year-long Randomised Controlled Trial. Eur Urol 72: 293-299.

16. Hojan K, Kwiatkowska-Borowczyk E, Leporowska E, Gorecki M, Ozga-Majchrzak O, et al. (2016) Physical exercise for functional capacity, blood immune function, fatigue, and quality of life in high-risk prostate cancer patients during radiotherapy: a prospective, randomized clinical study. Eur J Phys Rehabil Med 52: 489-501.
17. Abdalla DR, Murta EF, Michelin MA (2013) The influence of physical activity on the profile of immune response cells and cytokine synthesis in mice with experimental breast tumors induced by 7,12-dimethylbenzanthracene. Eur J Cancer Prev 22: 251-258.

18. Abdalla DR, Aleixo AA, Murta EF, Michelin MA (2014) Innate immune response adaptation in mice subjected to administration of DMBA and physical activity. Oncol Lett 7: 886-890.

19. Abdalla DR, Gomes BBM, Murta EFC, Michelin MA (2017) Bone marrow-derived dendritic cells under influence of experimental breast cancer and physical activity. Oncol Lett 13: $1406-1410$.

20. Bianco TM, Abdalla DR, Desidério CS, Thys S, Simoens C, et al. (2017) The influence of physical activity in the anti-tumor immune response in experimental breast tumor. Immunol Lett 190: 148-158.

21. Da Silva Alves $R$, Abdalla $D R$, lunes $D H$, Mariano KOP, Borges JBC, et al. (2020) Influence of an Exergaming Training Program on Reducing the Expression of IL-10 and TGF- $\beta$ in Cancer Patients. Games Health J 9: 446-452.

22. Hojan K, Kwiatkowska-Borowczyk E, Leporowska E, Milecki $P$ (2017) Inflammation, cardiometabolic markers, and functional changes in men with prostate cancer. A randomized controlled trial of a 12-month exercise program. Pol Arch Intern Med 127: 25-35.

23. Buffart LM, Newton RU, Chinapaw MJ, Taffe DR, Spry NA, et al. (2015) The effect, moderators, and mediators of resistance and aerobic exercise on health-related quality of life in older long-term survivors of prostate cancer. Cancer 121: 2821-2830.

24. Livingston PM, Craike MJ, Salmon J, Courneya KS, Gaskin CJ, et al. (2015) Effects of a clinician referral and exercise program for men who have completed active treatment for prostate cancer: A multicenter cluster randomized controlled trial (ENGAGE). Cancer 121: 2646-2654.

25. Lemanska A, Poole K, Griffin BA, Manders R, Saxton JM, et al. (2019) Community pharmacy life-style intervention to increase physical activity and improve cardiovascular health of men with prostate cancer: A phase II feasibility study. BMJ Open 9: e025114. 